\title{
Aikuiskoulutuksen organisaatiohistoriaa sitä harrastaville
}

Rainer Leskinen, Anu Talka \& Petri Pohjonen (1997) Ammatillisen aikuiskoulutuksen vaiheet. Pikakoulutuksesta aikuiskoulutuskeskuksiin. Ammatillisten Aikuiskoulutuskeskusten Liitto ry. Gummeruksen Kirjapaino Oy. $\triangle$ mmatillisten aikuiskouA lutuskeskusten liitto on laatinut neljännesvuosisataisen toimintansa kunniaksi historiikin. Teoksen nimi "Ammatillisen aikuiskoulutuksen vaiheet - Pikakoulutuksesta aikuiskoulutuskeskuksiin" kuvaa teoksen monia tavoitteita. Teos on ennen muuta ammatillisten kurssikeskusten muodostumisen historiaa, jonka jatkumona on niiden muuntuminen nimeltään ja toiminnaltaan Iaaja-alaisemmiksi ammatillisiksi aikuiskoulutuskeskuksiksi.

Teos on erinomainen lisä siihen 
ammatillisen koulutuksen ja aikuiskoulutuksen historiikkien sarjaan, joita on julkaistu useilta eri aloilta viime vuosikymmenen aikana. A mmatillisen aikuiskoulutuksen muuttuvasta kentästä kirja antaa hyvän kuvan sen teettäjän eli ammatillisten aikuiskoulutuskeskusten näkökulmasta. Muutos on ollut suuri: maailmansotaa edeltäneestä pikakoulutuksen kaudesta on edetty seitsemänkymmenluvun alun suuren rakennemuutoksen kautta jälkiteolliseen vaiheeseen, jossa totutut rakenteet ovat koetteilla. A mmatilliset kurssikeskukset perustettiin monien koulumiesten mielestä vain väliaikaisesti, vastaamaan seitsenkymmenluvun akuutteihin koulutustarpeisiin. Suomalainen koulutuspolitiikan historian yleisen linjan mukaisesti väliaikainen muuttuu kuitenkin pysyväksi: niin on käynyt kurssikeskuksillekin.

Teoksella on kolme kirjoittajaa, joista Rainer Leskinen vastaa ajanjaksosta, joka päättyy seitsenkymmenluvun puoliväliin. Tässä jaksossa on paljon uutta aineistoa, jota on saatu kokoon lähestymällä eri aikuiskoulutuskeskuksia. Niiden pöytäkirjoista ja omista historiikeista on löytynyt herkullisia ajankuvia kurssikeskustoiminnan alkuajoilta. M yös kurssikeskusten perustamista edeltänyt pikakoulutuksen vaihe ennen ja jälkeen toisen maailmansodan sisältää paljon uutta tutkimustietoa, jolla on käyttöä myöhemminkin.

K urssikeskusten perustamisen historia, jos mikään, on "miesten historiaa". Seitsenkymmenluvun alun rakennemuutoksessa luotiin teollisuus-
Suomen pikakvalifikaatioita. Tuota historiaa tehtiin diplomiinsinöörien johdolla, eivätkä kasvatustieteilijät olleet siinä hämmentämässä. (Tuskin heistä apua olisi ollutkaan.)

Rainer Leskinen on itse toiminut pitkään E telä-K arjalan ammatillisen aikuiskoulutuskeskuksen rehtorina ja hänet tunnetaan aikuiskoulutuskeskusten kentällä pitkäaikaisena vaikuttajana. Tämä näkyy asiantuntevassa ja perinpohjaisessa kirjoitustyylissä. K aipaamaan jää ehkä vain kurssikeskusten ja eri alojen ammatillisten oppilaitosten suhteen viileämpää analysointia: niiden välinen jännite tuodaan kyllä esille, mutta se jää usein marginaaliin.

$\Delta$ nu Talka on kirjoittanut A teoksen toisen pääjakson, jossa kuvataan aikuiskoulutuskeskusten toimintaa seitsenkymmenluvun lopulta lähtien. Historian tutkijana hän voi tarkastella lähihistorian tapahtumia hieman etäämpää, joten kirjan kahdesta pääjaksosta muodostuu tasapainoinen kokonaisuus. Talkalla on ollut käytettävissään myös uudempaa tutkimustietoa ammatillisen aikuiskoulutuksen uudistuksesta kymmenkunta vuotta sitten ja aikuiskoulutuskeskusten menestymisestä uudessa kilpailutilanteessa.

Teoksen tausta-aineistona on yli kuudenkymmenen ammatillisen aikuiskoulutuksen vaikuttajan haastattelut. 0 sa niistä on todellisten pioneerien puheenvuoroja, joiden dokumentointi on sellaisenaan arvokas koulutushistoriallinen teko. $\mathrm{H}$ aastattelut elävöittävät teosta monessa kohtaa hyvin.
Amatillisilla aikuiskoulutuskeskuksilla on ollut hallinnollisesti monta isäntää. Pikakoulutusajasta lähtien niiden asioita ovat ohjanneet ensin sosiaaliministeriö, kulkulaitosten ja yleisten töiden ministeriö sekä kauppa- ja teollisuusministeriö (ammattikasvatushallituksen muodostuessa). Pari vuosikymmentä ne ovat nyt toimineet ammattikasvatushallituksen, sittemmin opetushallituksen, opetusministeriön ja työministeriön muodostamassa Bermudan kolmiossa. Juhlahistoriikin luonteeseen kuuluu, että tätä jännitteistä asemaa ei koeta pulmalliseksi. I sännät ja emännät paäsevät kirjassa vähällä!

K iintoisaa ja innostavaa lukukokemustani laimensi juhlakirjan hieman "suttuinen" taulukko-osa. Pientä vaivaa on nähtävä myös lähdeviitteiden seuraamisessa. Silti suosittelen teoksen ääreen pysähtymään paitsi niitä, jotka ovat olleet ammatillisen aikuiskoulutuksen historiaa luomassa, myös niitä, jotka ovat sitä tänä päivänä kehittämässä ja tutkimassa. Puolessa vuosisadassa on ammatilliselle aikuiskoulutukselle luotu vahva perusta.

Tapio Varmola 